\title{
CONSEQUENCES OF TEENAGE PREGNANCY AMONG CHEPANG WOMEN IN KORAK VDC IN CHITWAN
}

I Adhikari (Poudel) ${ }^{1 *}$, B Thulung ${ }^{1}$, M Lopchan ${ }^{1}$

\author{
${ }^{1}$ College of Nursing, Chitwan Medical College, Bharatpur-13, Chitwan, Nepal \\ *Correspondence to: Ms. Indira Adhikari (Poudel), College of Nursing, Chitwan Medical College, Bharatpur-10, Chitwan, Nepal. \\ Email: Indira.adhikarip@gmail.com
}

\begin{abstract}
Teenage Pregnancy as "any pregnancy from a girl who is 10-19 years of age", the age being defined as her age at the time the baby is born. The objective of the study to identify the consequences of teenage pregnancy among the Chepang women in Korak village development committee in Chitwan. This study design was descriptive, cross sectional and 148 respondents were selected randomly and interviewed by using semi-structured questionnaires. Data entry was done by using Epi data and analyzed by SPSS. The study finding revealed that, majority of the respondents $56.1 \%$ had got married before the age of 16 years, $58.1 \%$ gave first child birth the age of $17-19$ years and $57.1 \%$ had $1-3$ numbers of children. Similarly, $10.1 \%$ had preterm birth, $18.2 \%$ had history of miscarriage and $99.3 \%$ had delivered at home. There was significant relationship between the age of child birth with complications of teenage pregnancy which gave birth before term $(p=0.020)$ and women having $\geq 4$ children had the difficulty to control urine during coughing and sneezing $(<0.001)$. the study concluded that there is a need of public awareness programme which can be done through orientation and training regarding reproductive health.
\end{abstract}

Key words: Consequences, Reproductive Organ, Teenage.

\section{INTRODUCTION}

Teenage pregnancy occurs when women aged less than 20 years become pregnant. This is of serious concern because maternal age plays a significant role in adverse outcome and complications of pregnancy. Teenage pregnancies represent a high-risk group in reproductive terms because of the double burden of reproduction and growth. Complications of pregnancy and childbirth are the leading cause of mortality among girls aged $15-19$ years in developing countries. ${ }^{1}$

Worldwide every $5^{\text {th }}$ child is born to teenage mother. Worldwide 13 million births each year occur to girls younger than 19 years. The incidence of teenage pregnancies varies dramatically between the different countries. Approximately $90 \%$ of the teenage births occur in developing countries. ${ }^{3}$

Early childbearing increases the risks for both mothers and their newborns. In low- and middle- income countries, babies born to mothers under 20 years of age face a $50 \%$ higher risk of being still born or dying in the first few weeks versus those born to mothers aged 20-29.2 Labor is often get slow and the baby becomes stuck, causing vesico and rectovaginal fistulas, and incontinence. In many societies, incontinence results in desertion by the husband, family and friends, leaving the girl's mother to look after her and her children. Also because of the larger number of child bearing years of young girls, increasing the chances of miscarriages, infant death ${ }^{3}$

Immaturity of the uterine or cervical blood supply in teenage pregnancy could increase the risk of subclinical infection and prostaglandin production, and lead to increased risk of pre-term delivery. ${ }^{4}$

Kumar, Parihar and Yasmin (2014) conducted prospective study on Impact of Teenage Pregnancy - Its Impact on Maternal and Fetal Outcome among 
672 teenage pregnancies in Gandhi Medical College, Bhopal, the study revealed that teenage pregnancy comprised $5.10 \%$ of the total obstetric admissions. Study shared that $53.12 \%$ teenage pregnancies had complications. The major maternal complications were preterm labour $27.45 \%$, hypertensive disorders of pregnancy $20.17 \%$, premature rupture of membranes $18.21 \%$, abortion $14.57 \%$ and anemia $8.12 \%$. Low Birth Weight (16.86\%), preterm births $(16 \%)$ and stillbirths (5\%) were major adverse fetal outcomes. $^{5}$

Child-brides are more likely to be forced into sexual activities and commence child bearing early, and are at higher risks of complications arising from early child bearing such as heavy bleeding, fistula, infections, anemia, eclampsia, obstructed labour and obstetric fistula, all due to the physical and sexual immaturity. ${ }^{6}$

\section{MATERIALS AND METHODS}

A descriptive research design was used to find out the consequences of teenage pregnancy among the Chepang women in Korak, village development committee in Chitwan. The population of the study was all those women from the age of 13 to 40 years who became pregnant between the age of 13 to 19 years. Probability simple random sampling technique was used to select the sample. The total sample size is 148 .

Semi structured interview schedule was developed by the researcher herself after reviewing of related literature. Content validity of the research instrument was established by consultation with subject exports, doctor and research adviser as well. The research instrument was translated into Nepali language to make it more clear and easy for taking information from the respondents. Pre-test was done among $10 \%$ of total sample in a similar setting. The sample was Chepang community of Lothar VDC in Chitwan. Data were collected from respondents using face to face interview method from 8 October to 13 November, 2014 by researcher herself.

Research approval was taken from Chitwan Medical College Institutional Review Committee (CMC- IRC) of Chitwan Medical College. Written permission was taken from the authority bodies of Korak VDC. The verbal informed consent was obtained from each respondent prior to data collection. The confidentiality of the respondents was maintained by coding the number instead of respondent's name, not disclosing the respondents' information to others and using the information for the study purpose only.

The collected data was edited and coded then entered Epi data. Data was analyzed using SPSS program version 20 . Both descriptive statistics like frequency, percentage, mean, standard deviation and inferential statistics such as chi-square test was used to find out the association between the consequences of teenage pregnancy with sociodemographic variables.

\section{TABLE 1: Socio-Demographic Characteristics of Respondents \\ $(n=148)$}

\begin{tabular}{|c|c|c|}
\hline Variables & Frequency & Percent \\
\hline \multicolumn{3}{|l|}{ Age group in years } \\
\hline$<20$ & 19 & 12.8 \\
\hline $20-29$ & 70 & 47.3 \\
\hline $30-39$ & 39 & 26.4 \\
\hline$\geq 40$ & 20 & 13.5 \\
\hline \multicolumn{3}{|c|}{ Mean $\pm S D=28.18 \pm 7.42$} \\
\hline \multicolumn{3}{|l|}{ Educational status } \\
\hline Literate & 94 & 63.5 \\
\hline Illiterate & 54 & 36.5 \\
\hline \multicolumn{3}{|c|}{ If literate, level of education ( $n=94)$} \\
\hline General education & 33 & 35.1 \\
\hline Primary education & 54 & 57.4 \\
\hline Secondary education & 7 & 7.5 \\
\hline \multicolumn{3}{|l|}{ Type of family } \\
\hline Joint & 87 & 58.8 \\
\hline Nuclear & 61 & 41.2 \\
\hline \multicolumn{3}{|l|}{ Occupation } \\
\hline Agriculture & 73 & 49.3 \\
\hline Household work & 74 & 50.0 \\
\hline Service & 1 & 0.7 \\
\hline
\end{tabular}

Table 1 shows that, highest percentage (47.3\%) of the respondents belonged to age group $20-29$ years and the mean age of respondents was 28.18 years with 7.42 standard deviation. Regarding the educational status, majority $(63.5 \%)$ of respondents 
were literate. Among literates, 57.4\% completed primary educational level and only $7.4 \%$ completed secondary education.

Regarding type of family, 58.8\% were living in joint family. Concerning the occupation of respondents, 49.3\% were engaged in agriculture and 50\% respondents were housewives.

TABLE 2: Respondents Age of Marriage, Age at First Child Birth and Children History $\quad(n=148)$

\begin{tabular}{|c|c|c|}
\hline Variables & Freq. & Percent \\
\hline \multicolumn{3}{|l|}{ Age of marriage } \\
\hline$<16$ & 83 & 56.1 \\
\hline$\geq 16$ & 65 & 43.9 \\
\hline \multicolumn{3}{|c|}{ Mean $\pm S D=15.48 \pm 1.509$} \\
\hline \multicolumn{3}{|l|}{ Having any child } \\
\hline Yes & 147 & 99.3 \\
\hline No & 1 & 0.7 \\
\hline \multicolumn{3}{|c|}{ Mother age at first child birth } \\
\hline 13-17 years & 62 & 41.8 \\
\hline $17-19$ years & 86 & 58.2 \\
\hline \multicolumn{3}{|c|}{ Mean $\pm S D=16.95 \pm 1.384$} \\
\hline \multicolumn{3}{|l|}{ Number of children } \\
\hline Up to 3 & 84 & 57.1 \\
\hline $4-6$ & 50 & 34.1 \\
\hline Above 6 & 13 & 8.8 \\
\hline \multicolumn{3}{|l|}{ Mean $\pm S D=3.41 \pm 2.170$} \\
\hline
\end{tabular}

Table 2 shows that majority (56.1\%) of the respondent's got married below the age of 16 . The mean age of marriage of respondents was 15.48 year with 1.509 standard deviation among married women. Almost all (99.3\%) of the respondents had children and one respondent did not have a child.

Regarding the age of first child birth, $41.3 \%$ had their first child birth at the age of less than 17 years and $58.1 \%$ had their first child birth at age of 17-19 years. The mean age at first child birth was 16.95 year with 1.384 standard deviation.

Regarding the total number of children, among 147 respondents, more than half $57.1 \%$ had up to
3 children. The mean number of children was 3.41 with 2.17 standard deviation.

TABLE 3: Association between Problems of Reproductive Organ and Genitourinary tract with Mother Age of Child Birth

\begin{tabular}{|l|l|l|l|l|}
\hline \multirow{2}{*}{ Variables } & \multicolumn{2}{|c|}{ Age at first child birth } & & \\
\cline { 2 - 3 } & $\begin{array}{c}<17 \text { years } \\
\mathbf{n}(\%)\end{array}$ & $\begin{array}{l}\geq 17 \text { years } \\
\mathbf{n}(\%)\end{array}$ & X2 & P value \\
\hline Reproductive organ & & & \\
\hline $\begin{array}{l}\text { Feel } \\
\text { something } \\
\text { coming } \\
\text { out from } \\
\text { vagina } \\
\text { during } \\
\text { squatting } \\
\text { position }\end{array}$ & $18(29.0)$ & $10(11.6)$ & 7.114 & $0.008^{*}$ \\
\hline
\end{tabular}

\section{Genitourinary problem}

\begin{tabular}{|l|l|l|l|l|}
\hline $\begin{array}{l}\text { Difficulty } \\
\text { to control } \\
\text { urine } \\
\text { during } \\
\text { coughing } \\
\text { and } \\
\text { sneezing }\end{array}$ & $15(24.2)$ & $6(7.0)$ & 8.771 & $0.003^{*}$ \\
\hline $\begin{array}{l}\text { Itching } \\
\text { around } \\
\text { genitals } \\
\text { parts }\end{array}$ & $14(22.6)$ & $16(18.6)$ & 0.352 & 0.553 \\
\hline $\begin{array}{l}\text { Foul } \\
\text { vaginal } \\
\text { discharge }\end{array}$ & $17(27.4)$ & $12(14.0)$ & 4.146 & $0.042 *$ \\
\hline
\end{tabular}

*Significance level at 0.05 ï Fishers exact test $\quad \ddot{i}$ Yate's correction of continuity

Table 3 shows that there was statistical association between respondents age at first child birth with "feeling of something coming out from vagina during squatting" position ( $p=0.008)$, "difficulty to control urine during coughing and sneezing" $(p=0.003)$ and foul vaginal discharge $(p=0.042)$.

Similarly, itching around genital part $(p=0.553)$ was not statistically significance with respondents age of first child birth. 
Poudel et al, Journal of Chitwan Medical College 2016; 6(16)

TABLE 4: Association between Problems during Pregnancy and Postpartum with Number of Children

\begin{tabular}{|c|c|c|c|c|}
\hline Variables & $\begin{array}{l}<4 \text { child } \\
n(\%)\end{array}$ & $\begin{array}{c}\geq 4 \text { child } \\
\text { n (\%) }\end{array}$ & $x^{2}$ & $P$ value \\
\hline $\begin{array}{c}\text { Pregnancy } \\
\text { problems } \\
\text { Vaginal } \\
\text { bleeding }\end{array}$ & $8(9.5)$ & $6(9.4)$ & 0.001 & 0.976 \\
\hline $\begin{array}{c}\text { Baby before } \\
\text { term }\end{array}$ & 10(11.9) & $5(7.8)$ & 0.668 & 0.414 \\
\hline $\begin{array}{c}\text { Blurred } \\
\text { vision }\end{array}$ & $3(3.3)$ & $11(17.2)$ & 6.354 & $0.012 \dddot{\pi i ̈}$ \\
\hline Edema & $3(3.6)$ & $11(17.2)$ & 7.863 & $0.005 \pi$ \\
\hline Miscarriage & $14(16.7)$ & $13(20.3)$ & 0.324 & 0.569 \\
\hline $\begin{array}{c}\text { Postpartum } \\
\text { problems } \\
\text { Vaginal } \\
\text { bleeding }\end{array}$ & $12(14.3)$ & $21(32.8)$ & 7.169 & $0.007^{*}$ \\
\hline $\begin{array}{c}\text { High } \\
\text { temperature }\end{array}$ & $8(9.5)$ & $15(23.4)$ & 5.358 & $0.021^{*}$ \\
\hline $\begin{array}{c}\text { Breast } \\
\text { abscess }\end{array}$ & $6(7.1)$ & $13(20.3)$ & 5.630 & $0.018^{*}$ \\
\hline $\begin{array}{l}\text { Foul vaginal } \\
\text { discharge }\end{array}$ & $5(6.0)$ & $8(12.5)$ & 1.944 & 0.163 \\
\hline
\end{tabular}

*Significance level at 0.05 ïFishers exact test $\dddot{̈}$ Yate's correction of continuity

Table 4 shows association between numbers of children with respondent's problems during pregnancy. Blurred vision $(p=0.012)$ and swelling of the legs $(p=0.005)$ was associated significantly. Vaginal bleeding after delivery $(p=0.007)$, breast abscess $(p=0.018)$ and high temperature $(p=0.021)$ are also statistically association with respondents' number of children. Problem is higher in those mothers who have more than four children.

But, vaginal bleeding during pregnancy $(p=0.976)$, baby born before term $(p=0.414)$, miscarriage $(p=0.569)$ and foul vaginal discharge $(p=0.163)$ is not statistically associated with respondents' number of children.
TABLE 5: Association between Problems of Reproductive Organ and Genitourinary Tract with Number of Children

\begin{tabular}{|c|c|c|c|c|}
\hline \multirow[b]{2}{*}{ Variables } & \multicolumn{2}{|c|}{$\begin{array}{l}\text { Number of } \\
\text { Children }\end{array}$} & \multirow[b]{2}{*}{$x^{2}$} & \multirow[b]{2}{*}{$P$ value } \\
\hline & $\begin{array}{l}<4 \\
\text { child } \\
\text { n (\%) }\end{array}$ & $\begin{array}{l}\geq 4 \text { child } \\
n(\%)\end{array}$ & & \\
\hline $\begin{array}{l}\text { Reproductive } \\
\text { organ } \\
\text { Feel } \\
\text { something } \\
\text { coming out } \\
\text { from vagina } \\
\text { during } \\
\text { squatting } \\
\text { position }\end{array}$ & $6(7.1)$ & $22(34.4)$ & 17.561 & $<0.001 *$ \\
\hline $\begin{array}{l}\text { Genitourinary } \\
\text { problem } \\
\text { Difficulty } \\
\text { to control } \\
\text { urine during } \\
\text { coughing and } \\
\text { sneezing }\end{array}$ & $5(6.0)$ & $16(25.0)$ & 10.824 & $<0.001^{*}$ \\
\hline
\end{tabular}

Table 5 shows the problems of reproductive organ, that is feel something coming out from vagina during squatting position $(<0.001)$ is significantly associated with respondents' number of children. Regarding genitourinary tract problems, difficulty to control urine during coughing and sneezing $(<0.001)$ and problems of incontinence of urine $(p=0.0316)$ is also statistically significant.

\section{DISCUSSION}

Socio demographical finding of the study revealed that, the mean age of marriage of the respondents were 15.48 year, mean $\pm S D$ was $15.48 \pm 1.509$ and the mean number of children was 3.41. Another finding of the similar study conducted by Mostafa, K, (2007) found that the mean age of marriage of respondents was 15.5 years, mean $\pm S D$ was $15.5 \pm 3.0$ and the mean number of children among was $3.1 .^{7}$

Concerning the prolonged labor, the study found that $20.3 \%$ of the respondents had prolonged labor. 
This finding was in contradicts to the finding of the study conducted by Huang et al. (2014) reveals that $2.7 \%$ of the respondents had prolonged labor. ${ }^{8}$

The finding of the study shows that, out of 148 respondents $18.2 \%$ had abortion. This finding was supported by the another similar study finding conducted by Kumar, Pariyar and Yasmina, (2014) done on Teenage Pregnancy Its Impact on Maternal and Fetal Outcome Gandhi Medical College, Bhopal. Out of 672 teenage mother, $14.57 \%$ had abortion. ${ }^{5}$

The study found that, $9.5 \%$ of the respondents had vaginal bleeding during pregnancy. This study finding was supported by the another similar finding conducted by Pun and Chauhan, (2011) which revealed that $2.4 \%$ had bleeding during pregnancy. ${ }^{9}$

The finding of the study shows that, $19.0 \%$ of the respondents had problems of postpartum haemorrhage before the age of 17 which was higher and $17.4 \%$ had at $\geq 17$ which was lower. The finding of the study was supported by the study conducted by Blomberg, Tyrbery and Kjolhede, (2014) which revealed that $30 \%$ of the respondents had $\mathrm{PPH}$ before 17 which was higher and $2.7 \%$ has at $\geq 17$ which was lower. ${ }^{10}$

Regarding the problem during pregnancy, $10.1 \%$ of the respondents had preterm birth among teenagers. The finding of the study done by Mukhopadhyay et. al. (2010) revealed that $27.7 \%$ of mother had preterm delivery among teenagers. ${ }^{1}$

\section{CONCLUSION}

Based on the findings of the study it can be concluded that there are some reasons behind the occurrence of these consequences. Firstly, most of all Chepang women were having only general and basic education. Secondly, women were not taking maternal and child health services from health institution. So, due to teenage pregnancy many problems are seen in Chepang women through life time. There is a need of public awareness programme which can be done through orientation and training regarding reproductive health to minimize the consequences of teenage pregnancy.

\section{REFERENCE}

1. Mukhopadhyay ,Chaudhuri, Paul. Hospitalbased Perinatal Outcomes and Complications in Teenage Pregnancy in India 2010. Retrieved from http://www.ncbi.nlm.nih.gov/pmc/ articles/PMC2963772/

2. World Health Organization. Factsheets of WHO 2014. Retrieved from http://www.who.int/ mediacentre/factsheets/fs364/en/

3. UNICEF Malaysia Communications, Fact sheet of World Population day 2009 July 11. Retrieved from http://www.unicef.org/ malaysia/ Teenage_Pregnancies_Overview.pdf

4. Aparna J. Late teenage pregnancy and reproductive outcomes. Annals of Biological Research, Department of Obstetrics and Gynecology, Andhra Pradesh, India 2013; 4(11):67-69. Retrieved from www.scholarsresear chlibrary.com

5. Kumar, Pariyar, Yasmin. The teenage pregnancyits impact on maternal and fetal outcome. International journal of scientific study 2014;1:6. March. Retrieved from http://www.ijss-sn.com /uploads/2/0/1/5/20153321/ijss_mar-02.pdf

6. Olaide AA, Adeyemi EE, Dauda C. Child Marriage and Maternal Health Risks among Young Mothers in Gombi, Adamawa State, Nigeria.

Sixth African population conference, Burkina Faso, 2011. Available at: http://uaps2011.princeton. edu/papers/110373

7. Mostafa SM. Decline in Child Marriage and Changes in Its Effect on Reproductive Outcomes in Bangladesh. Journal of Health Population and Nutrition 2012;30(3):317-330.

8. Huang CC, Lin YC, Huang YT, Huang $\mathrm{KH}$. Comparison of medical issues in antenatal and perinatal periods in early youth, adolescent, and young adult mothers in Taiwan. British Medical Journal 2014;14:260. Retrieved from http:// www.biomedcentral.com/1471-2393/14/260 
9. Pun K D, Chauhan M. Outcomes of Adolescent Pregnancy at Kathmandu University Hospital, Dhulikhel, Kavre, Kathmandu University Medical Journal. 2011;33(1):50-3.

10. Blomberg M, Tyrberg RB, Kjolhede P. Impact of maternal age on obstetric and neonatal outcome with emphasis on primiparous adolescents and older women: A Swedish Medical Birth Register Study. 2014 Retrieved from http://bmjopen. bmj. com/content/4/11/e005840 